\title{
A SOCIOLINGUISTIC ANALYSIS OF INDOGLISH PHENOMENON IN SOUTH JAKARTA
}

\author{
Angelina Diva Wijaya ${ }^{1}$, Barli Bram ${ }^{2}$ \\ 1,2 Sanata Dharma University \\ 1 divangelina999@gmail.com, ${ }^{2}$ barli@usd.ac.id
}

\begin{abstract}
This paper investigated the variety of code-mixing expressions in the Indoglish phenomenon which happens in South Jakarta or Jaksel, for short. Interestingly, Indoglish has become a communication means among teenagers. The researchers chose this topic since it went viral and interesting. This research was conducted to identify the words which are frequently used as Indoglish expressions. The researchers used sociolinguistic analysis as the method of this study. There were 12 tweets from 8 websites to be investigated. The data were then identified and analyzed to explore the Indoglish phenomenon. Results showed there were 78 English words from 12 tweets in eight websites, revealing the four most frequently words as Indoglish expressions. The Indoglish phenomenon was popular among teenagers in the bilingual or mulitilingual society when communicating with their online friends, for example when making jokes and Indoglish was considered prestigious.
\end{abstract}

Keywords: Indoglish, Sociolinguistics, Code-Mixing, Communication, South Jakarta

\section{INTRODUCTION}

Communication has become an essential tool between humans and the surroundings. It is indispensable in daily life to deliver and transfer any information. In reality, people can communicate through verbal and non-verbal to interact with each other. Moreover, people use language to communicate specifically to express their ideas and feelings among others. As Linell (2005) stated, "languages as structured sets of forms, used to represent things in the world". It is seen as "modernization", "development", and "globalisation" (Nardi, 1995). Language is not only a powerful tool to communicate between two people but also among society. Language depicts people's social behaviour. Moreover, social studies can be included in the analysis of language in talk or written (Rapley, 2018). As Hudson (1980) stated that sociolinguistic is about the relation between language and society (as cited in Calteaux, 1994), this study focuses on a sociolinguistics analysis of one phenomenon that happens among teenagers in a certain area in Jakarta.

Some scholars defined Indoglish as a phenomenon that happened in some places in Indonesia. The phenomenon mentioned as the Indoglish phenomenon currently happens among teenagers in Jakarta Selatan (Jaksel). Indoglish arises from the use of Bahasa Indonesia and English in daily conversation both formal and informal. Riadil stated that Indonglish is a term that is often used for language usage in English that is still nuanced in Indonesian culture and language (2019). Indoglish also shows searching for self-identity for teenagers who are curious and they want to do experiments, including language use (Saddhono, 2016). According to Khotimah, the language attitudes of the young people towards Indoglish on social media platforms refer to show their personal identities (2020).

Teenagers in South Jakarta mix and switch in two languages, namely English and Indonesian, 
to communicate informally or even to tell jokes. They borrow another language which means one language originally had a word and the speakers of another imitated it and introduced it to their language (McMahon, 1994). In Sociolinguistics they are called code-mixing and codeswitching. Code-switching is "the alternative used by bilinguals of two or more languages in the same conversation (Milroy \& Musyken, 1995, as cited in Ariffin, 2011)." Mabule, D.R also stated "code-switching and code-mixing are phenomena which occur regularly in multilingual communities reflecting social group memberships (2015). They also defined that code-mixing as expressions in which a mixture of the grammar of one language and another language is used without altering the grammar of the first language used (Mabule, 2015). Therefore, Ariffin (2011) declared that code-mixing and code-switching can promote better understandings and effective teaching and learning.

According to Fishman (1971), it's essential to decide who is speaking, to whom someone is speaking, what is being spoken, and when someone is speaking in sociolinguistics (as cited in Calteaux, 1994). Holmes (2013) also stated, "certain social factors have been relevant in accounting to the particular variety used; relate to users of language, social setting, and function of the interaction". Mabule also mentioned one of the 6 functions and reasons why people code mix or code switch; to affirm one's identity and sometimes social status (2015). Another reason is the willingness to accept English vocabulary (Mabule, 2015). As a result, the researchers used four social dimensions in sociolinguistics to analyze the phenomenon (Holmes, 2013), namely: 1. A social distance scale, 2. A status scale, 3. A formality scale, and 4. Functional scales.

This phenomenon first debuts on Twitter with hash tags Anak Jaksel or bahasaJaksel (\#AnakJaksel, \#bahasaAnakJaksel). That searching those hashtags can lead us to thousand tweets of the Indoglish phenomenon in Jakarta Selatan. The background of this emergence is because mixing Bahasa Indonesia and English is cool and teenagers call it prestige. This emergence arises among teenagers who are following their favourite public figures and actors or actress. Teenagers in general will feel prestigious when they can follow the trends carried out by celebrities, one of which is related to the use of the language (Riadil, 2019). Therefore, the researchers investigated the variety of Indoglish vocabulary and analyze this phenomenon through sociolinguistics perspectives by identifying the words which are being used as Indoglish expression and analyzing the phenomenon. The researchers formulated two research questions. First, what are the words which mostly being used as Indoglish expressions? Second, what is the analysis of this phenomenon?

\section{METHOD}

This research uses sociolinguistics analysis. The researchers used four social dimensions in sociolinguistics to analyze the phenomenon from Holmes (2013); A social distance scale which concerned with participant relationship, a status scale which concerned with participant relationship, a formality scale which is relating to the setting or type of interaction, and functional scales which are relating to the purposes or topic of interaction.

The researchers collected the data by reading and identifying some tweets from certain social media which is called Twitter by using certain hashtags; \#AnakJaksel, \#bahasaAnakJaksel. It can be found through Google Image by typing those hashtags. The researchers chose some websites; www.idntimes.com, www.liputan6.com, www.inibaru.id, www.health.detik.com, www.suara.com, www.news.okezone.com, www.jakarta.tribunnews.com and www.brilio.net to get the articles about this Indoglish phenomenon. Then, the researchers analyzed the data by 
paying attention to the language of the words and taking notes related to them. The researchers identified the data by collecting the words used as code-mixing and splitting the words which are often used by them. Finally, the researchers analyzed the phenomenon using four dimensions by Holmes (2013). The documents' review and identification are designed to identify the language phenomenon which is happened among Indonesian teenagers in Jakarta Selatan.

The researchers downloaded the pictures or images from some websites in Google. There are 8 websites which are explored. The researchers found the 12 most viral tweets from those websites. Therefore, the researchers identified the images, analyzed the words, and collected the words which were used in the Indoglish phenomenon. The columns were divided into three parts; website link, pictures of tweets, words as Indoglish expression. Therefore, the writers presented the results by showing the picture and analyzing the phenomenon in the results.

\section{RESULTS AND DISCUSSION}

\section{Results}

This chapter discusses the analysis of the result and discussion. The researchers found the 11 most interesting tweets which were taken from 8 websites. There were 12 different tweets from various accounts with the hashtag \#AnakJaksel. The findings were interesting since the researchers found some public figure accounts who followed this phenomenon; Ernest Prakasa and Sandiaga Uno. Ernest Prakasa is one of the most famous actors in Indonesia who started his career as a comedian. Sandiaga Uno is an Indonesian businessman and famous politician. He was elected as vice governor in Jakarta and proposed as vice president with Prabowo Subianto. The 12 most interesting tweets, therefore, were listed within the website link and English words which were used in this phenomenon. They were listed as follows:

Datum 1

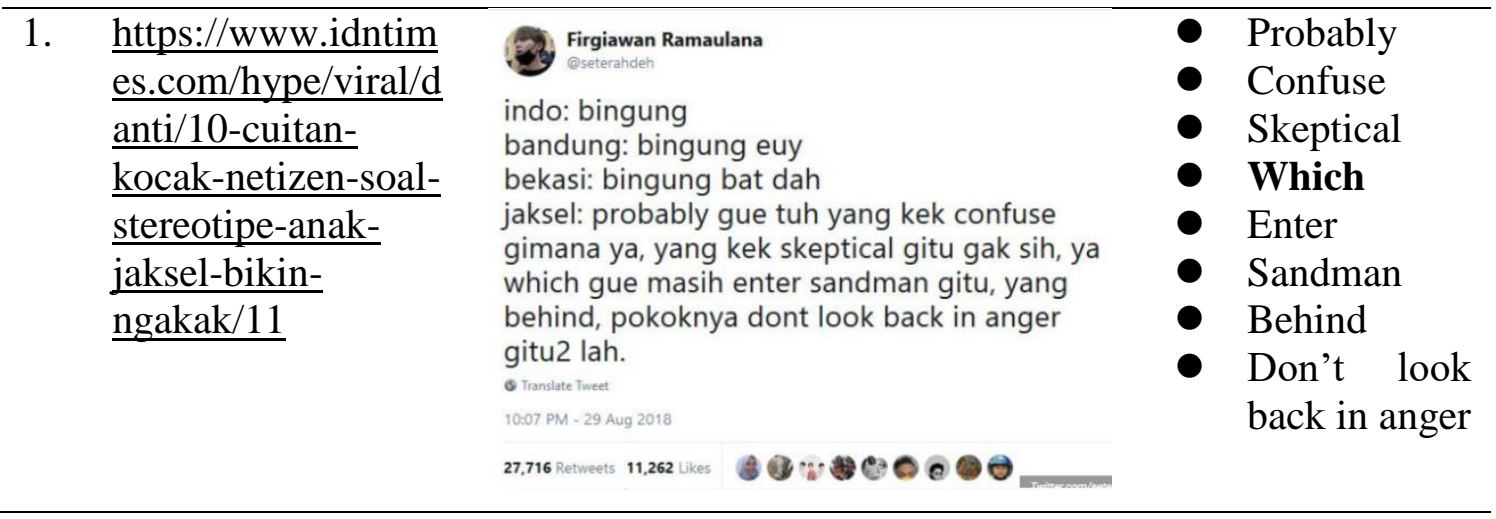

This tweet was created by @ seterahdeh and taken from www.idntimes.com. He exposed the use of the word "bingung" as Bahasa Indonesia in several areas. According to him, each area has a different style of expressing the word "bingung" which means "confuse" in English. Indonesian tend to say "bingung", people in Bandung tend to say "bingung euy", people in Bekasi tend to say "bingung bat dah" while people in South Jakarta (Jaksel) tend to add more words and mix it with English words; "probably gue tu yang kek confuse gimana ya, yang kek skeptical gitu gak sih, ya which gue masih enter sandman gitu, yang behind, pokoknya don't look back in anger gitu2 lah. 
This tweet has clarified that Firgiawan as the writer tried to explicitly differ the language style in some places. He exposed that South Jakarta people had their style of communicating. It's seen that they're communicating by simply mixing the languages; Bahasa Indonesia and English. Code-switching is "the alternative used by bilinguals of two or more languages in the same conversation (Milroy and Musyken,1995, as cited in Ariffin, 2011).

Datum 2

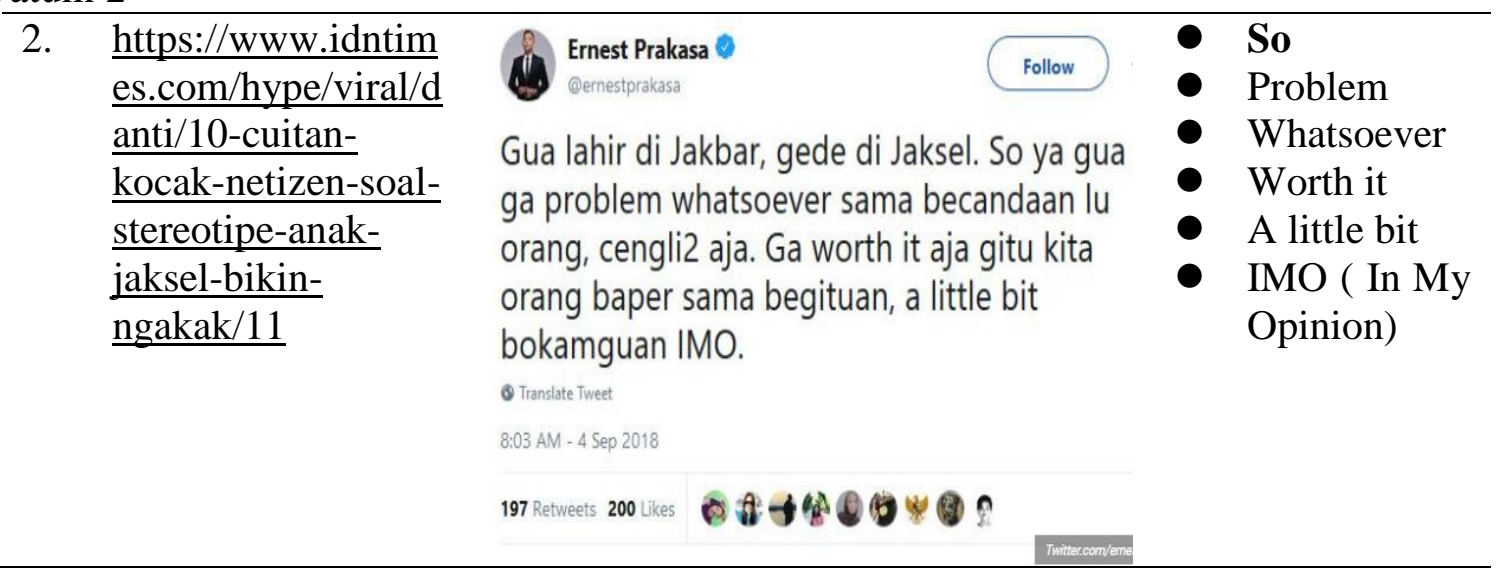

This tweet was created by one famous Indonesian comedian, Ernest Prakasa (@ernestprakasa), and taken from www.idntimes.com. In his tweet, he tried to show that he was born in West Jakarta but grew in South Jakarta where people in this area used Indoglish expressions by mixing the languages; Bahasa Indonesia and English to communicate. Indonglish is a term that is often used for language usage in English that is still nuanced in Indonesian culture and language (Riadil, 2019).

He displayed the style of Jaksel expression in communicating. The researchers collected some English words from this tweet; so, problem, whatsoever, worth it, a little bit, IMO ( In my opinion).

\section{Datum 3}

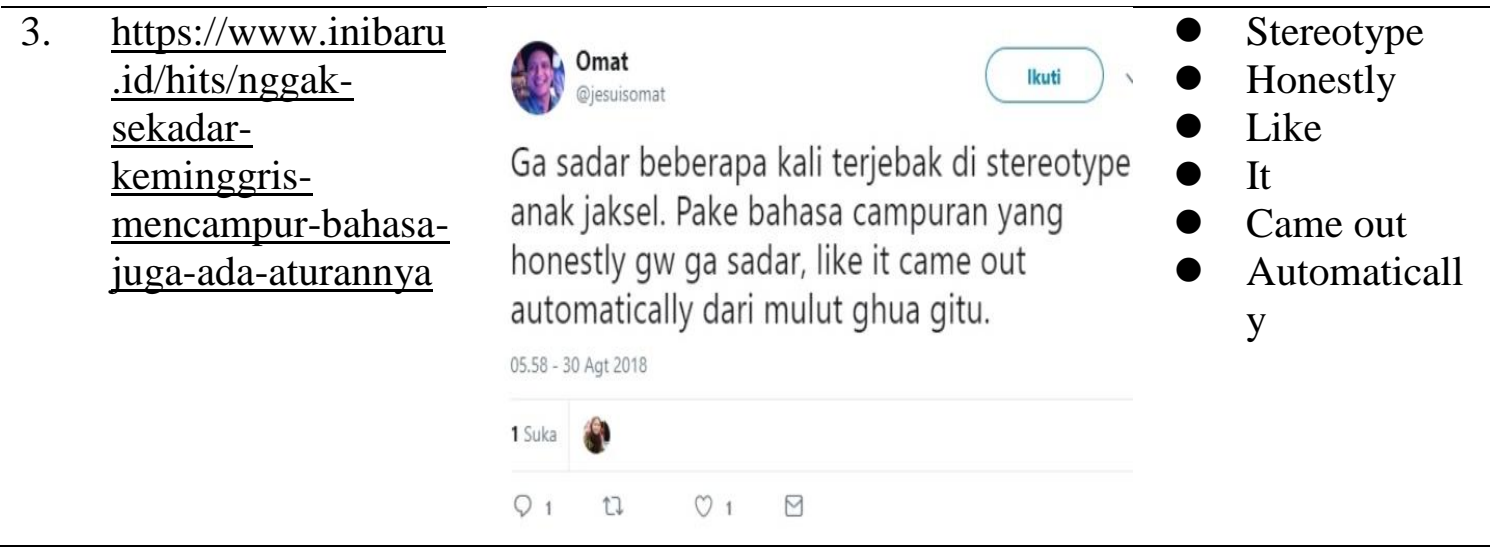

This tweet was created by @jesusisomat and taken from www.inibaru.id. He stated that he's trapped in Jaksel teenagers' stereotype several times. He explained that the stereotype referred to the use of code-mixing which made him unconsciously adjust it by saying "it came out automatically from his mouth". He's unconsciously mixing the language when he tweeted it. 
This tweet displayed that mixing the language has been being the new style of communication in South Jakarta. Thus, people would easily determine Jaksel style of language. The researchers collected 6 English words from this tweet; stereotype, honestly, like, it, came out, automatically.

Datum 4

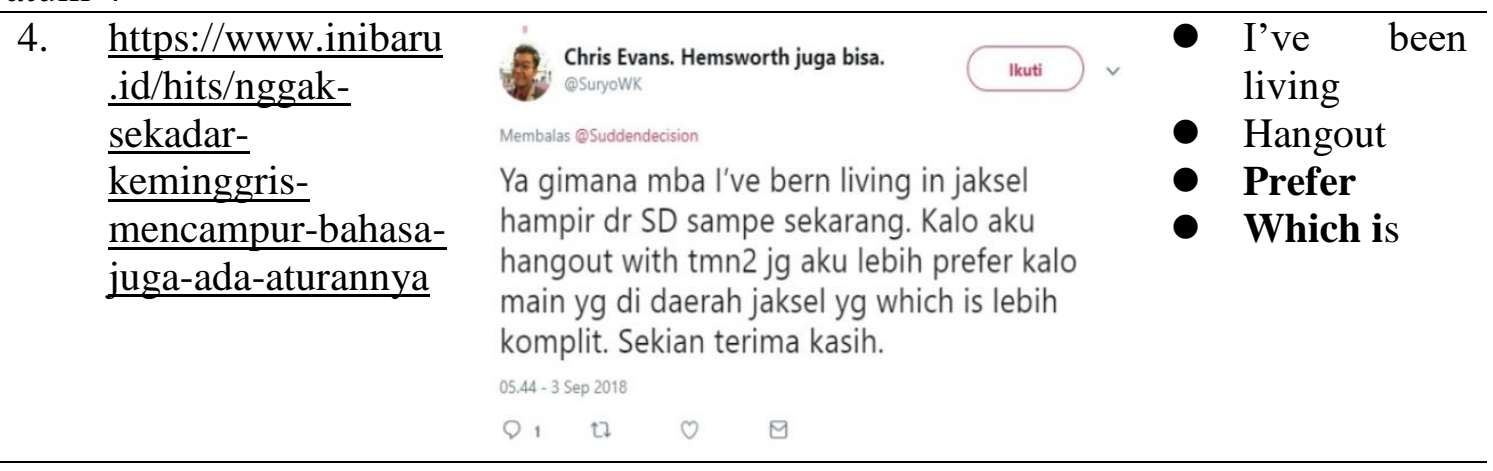

This tweet was created by @ SuryoWK and taken from www.inibaru.id. He stated that he's been living in South Jakarta (Jaksel) since he was an elementary student until now. He said that he'd prefer to hang with his Jaksel friends because it's more complete. He mixed the language both Bahasa Indonesia and English while tweeting it as McMahon (1994) also stated that they borrow another language which means one language originally had a word and the speakers of another imitated it and introduced it to their own language. Furthermore, there are some English words collected from this tweet; I, have, been, living, hangout, prefer, which is.

Datum 5

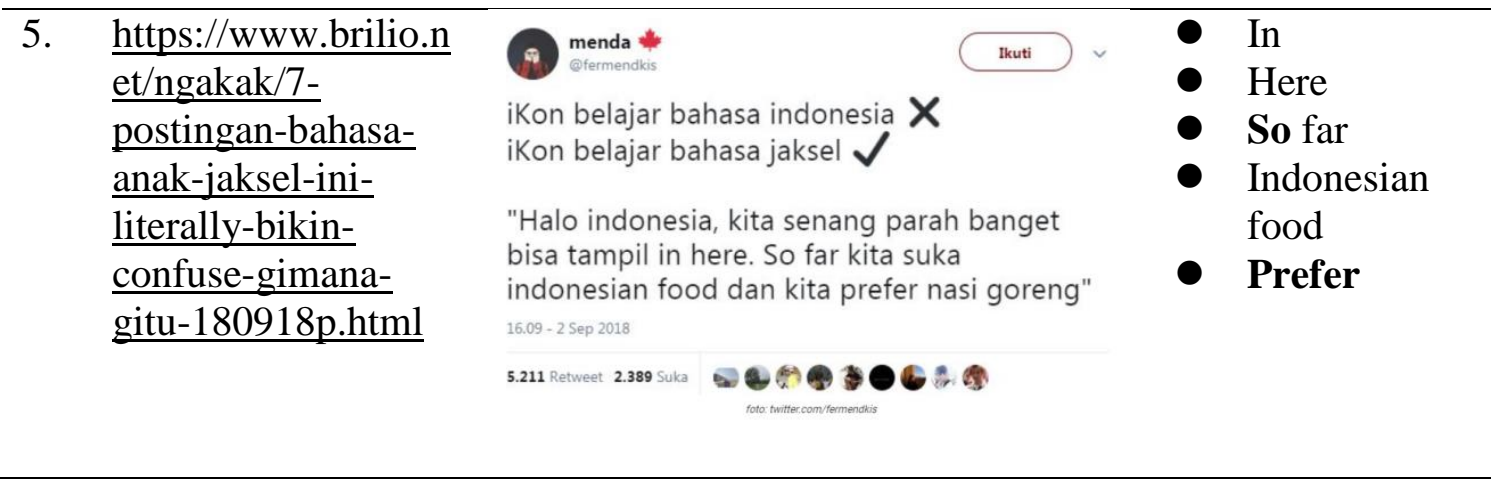

This tweet was created by @fermendkis and taken from www.brilio.net. It's stated about how to learn the Jaksel language. It's said, "Halo Indonesia., kita senang parah banget bisa tampil in here. So far kita suka Indonesian food dan kita prefer nasi goreng". This account has mixed the language. Code-switching is "the alternative used by bilinguals of two or more languages in the same conversation (Milroy and Musyken,1995, as cited in Ariffin, 2011). It means, "Halo Indonesia, we are happy to perform here. So far we love Indonesian food and prefer fried rice". There are some English words collected from this tweet; in, here, so, far, Indonesian, food, prefer. 
Datum 6

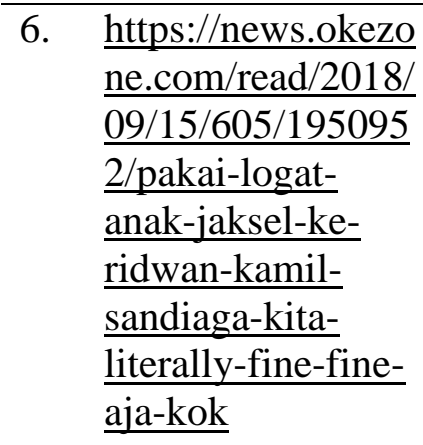
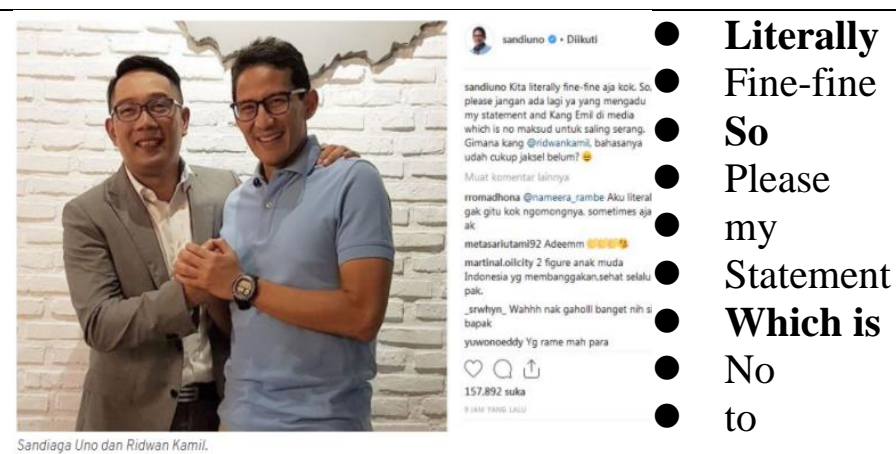

Sandiaga Salahuddin Uno

@sandiuno

Kita literally fine-fine aja kok. So, please jangan ada lagi ya yang mengadu my statement and Kang

Emil di media which is no maksud to

saling serang. Gimana kang

@ridwankamil, bahasanya udah

cukup jaksel belum? s

This tweet was created by @Sandiuno or Sandiaga Uno and taken from www.news.okezone.com. He is a famous politician and businessman in Indonesia. He wrote his tweet by showing his picture with Ridwan Kamil (the Governor of West Java). He mixed the language to explain that his relationship with Ridwan Kamil was fine and there's no tendency to attack each other. It can be seen that the writer did not change the grammar of the first language but only change some words into English and mix them altogether. It is proven by Mabule's statement "code-mixing is expressions in which a mixture of the grammar of one language and another language is used without altering the grammar of the first language used" (2015). He also asked a question at the end of the tweet wondering whether his language had belonged to the Jaksel language or not. It denoted that this has been becoming a language style in South Jakarta. The researchers collected 10 English words in this tweet; literally, fine-fine, so, please, my, statement, which, is, no, to.

Datum 7

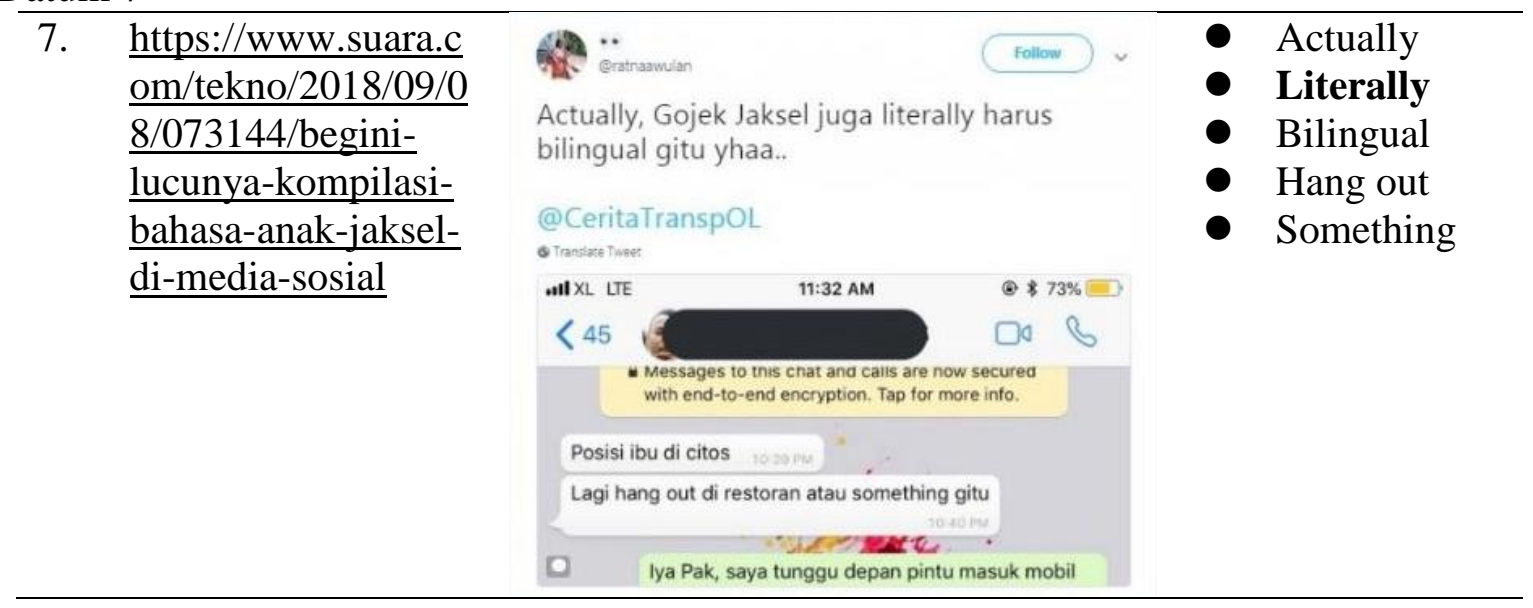


This tweet was created by @ ratnaawulan and taken from www.suara.com. She exposed that even Gojek (Indonesian motorbike taxis) in South Jakarta must be bilingual as well. As she attached the conversation between a Gojek driver with a customer asking the customer's position while mixing the language; "Lagi hang out di restoran atau something gitu". In this conversation, the driver's asking whether the customer's in the restaurant or somewhere else. It's seen that the driver's willing to learn English by mixing some English words into his/her conversation with the customer. People codemix the language because of the willingness to accept English vocabulary (Mabule, 2015).

As mentioned by Holmes (2013) "certain social factors have been relevant in accounting to the particular variety used; relate to users of language, social setting and function of the interaction". The researchers collected five English words from this tweet; actually, literally, bilingual, hang out, something.

\begin{tabular}{|c|c|c|c|}
\hline \multicolumn{4}{|c|}{ Datum 8} \\
\hline & \multirow{8}{*}{$\begin{array}{l}\text { https://www.inibaru } \\
\text { id/hits/kata- } \\
\text { mereka-soal- } \\
\text { bahasa-keminggris- } \\
\underline{\text { ala-anak-jaksel-lp }}\end{array}$} & & \multirow{8}{*}{$\begin{array}{ll} & \text { From } \\
\text { - } & \text { What } \\
\text { - } & \text { I } \\
\text { - Which is } \\
\text { - } \\
\text { - } \text { Hence } \\
\text { - } \text { Its fine } \\
\text { - Like } \\
\text { - Literally }\end{array}$} \\
\hline & & & \\
\hline & & from what i gathered, padinya ditumbuk & \\
\hline & & $\begin{array}{l}\text { which is bijinya lepas gitu nah moreafter } \\
\text { dikumpulin deh itu hence masi ada kulitnya } \\
\text { its fine baru abis itu ditumbuk2 like biar jadi } \\
\text { beras literally }\end{array}$ & \\
\hline & & -petani jaksel & \\
\hline & & o Trassater Tweer & \\
\hline & & 11:37 AM- 28 Aug 2018 & \\
\hline & & 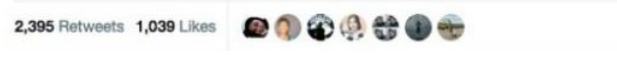 & \\
\hline
\end{tabular}

This tweet was created by @iyajgybg and taken from www.inibaru.id. In this case, the writer tried to explain how a farmer processing the paddy to become rice. It's shown at the end of the tweet by mentioning - petani jaksel which referred to the farmer in South Jakarta.

The writer wanted to be approved as a South Jakarta farmer who used its Indoglish style in communicating. Again, the use of Indoglish expression is purposed to seek identity. The researchers collected 8 English words as mentioned above.

Datum 9

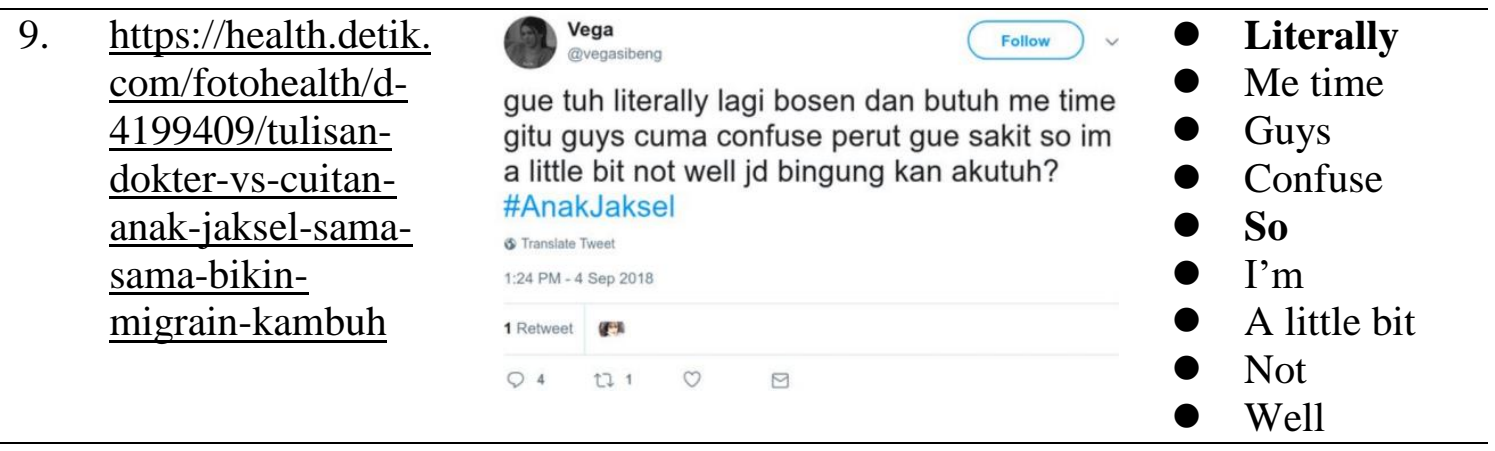

This tweet was yielded by @ vegasibeng and taken from https://health.detik.com. She shared her feeling about getting bored and needing a "me time" but she got a stomachache. She's 
unconsciously confused by her own words which are mixed. In this case, the writer tried to affirm her identity as South Jakarta people by mixing the languages. One of the 6 functions and reasons why people code mix or code switch; to affirm one's identity and sometimes social status (Mabule, 2015). The researchers collected twelve English words from this tweet such as literally, me time, guys, confuse, so, I'm, a little bit, not, well.

Datum 10

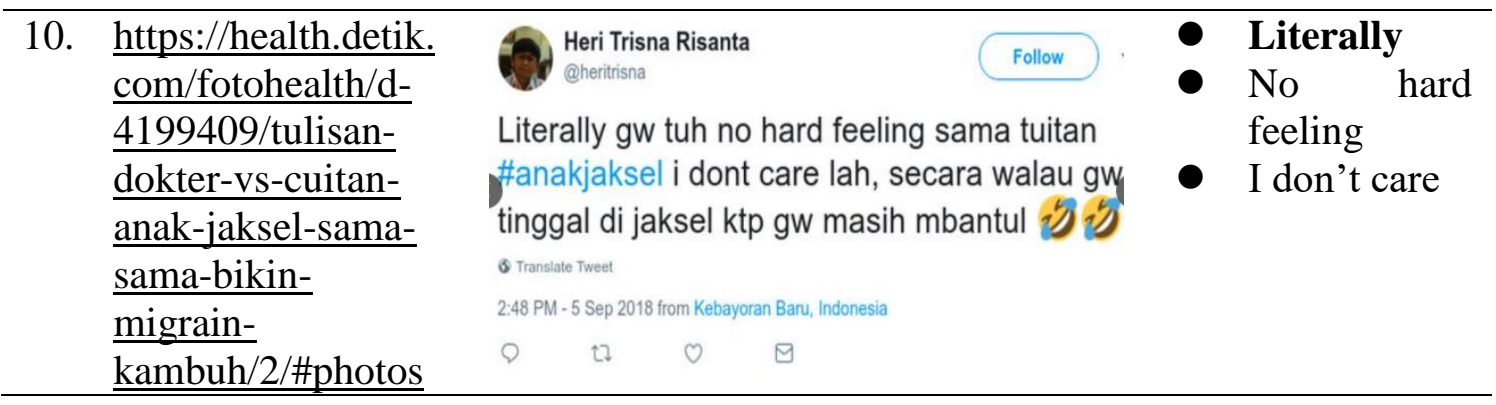

This tweet was prompted by @ heritrisna and taken from https://health.detik.com. As Khotimah stated that the language attitudes of the young people towards Indoglish on social media platforms refer to show their personal identities (2020), the writer's following the style of Jaksel teenagers by mixing the languages.

The researchers collected 7 English words from this tweet. They are literally, no hard feelings, I don't care. He revealed that he had no feeling about Jaksel teenagers' tweets.

Datum 11

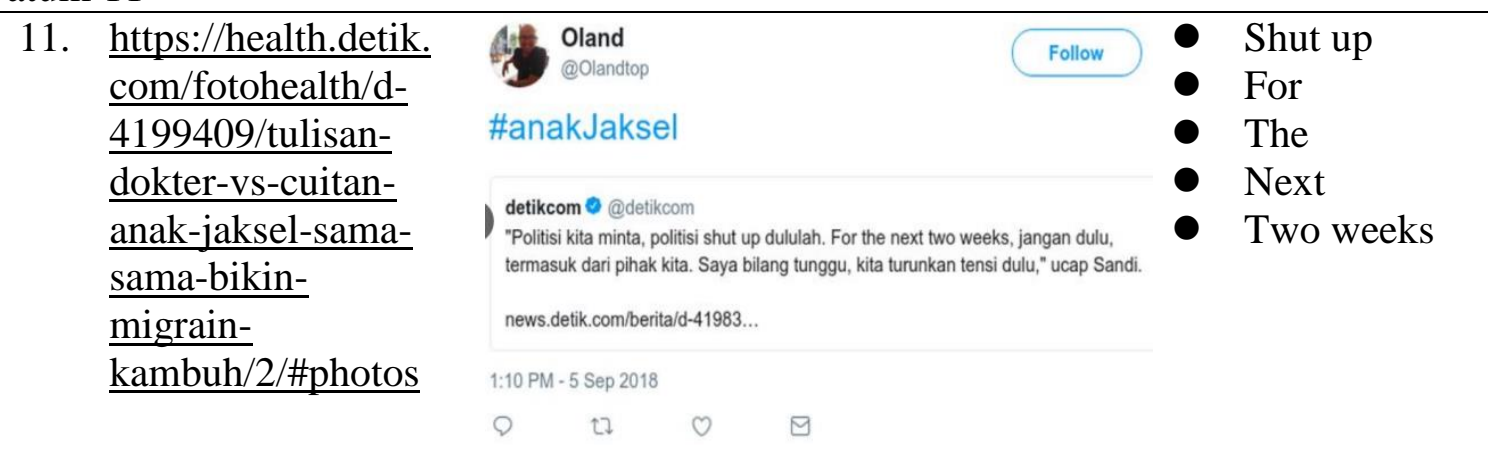

This tweet was created by @olandtop and taken from https://health.detik.com. He's only commenting on other tweets from @ detikcom about a piece of news which uses Indoglish expression by tagging "anakJaksel". The writer attached the hashtag of anakJaksel in order to follow the phenomenon and get accepted among the community. The researchers collected 6 English words from this tweet. There are shut up, for, the, next, two, weeks.

Datum 12

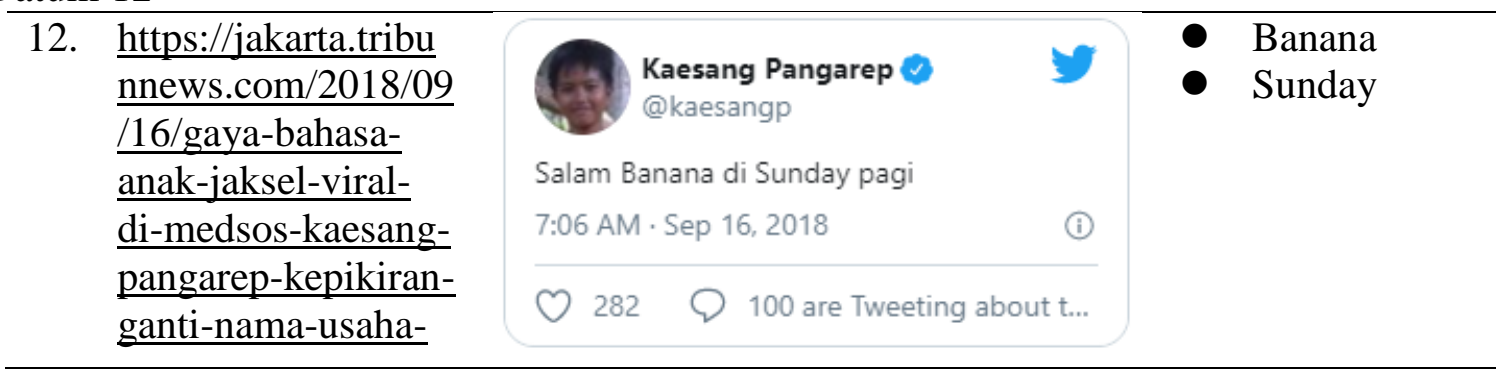




\section{sang- \\ pisang?page $=$ all}

The last tweet was spawned by the son of the Indonesian president, @kaesangp, and taken from https://jakarta.tribun. As Khotimah stated that the language attitudes of the young people towards Indoglish on social media platforms refer to show their personal identities (2020), we can see that the writer used Indoglish expression in his social media.

In this tweet, the purpose of @kaesang was just to greet the audience by mixing the language. The researchers collected two English words; banana and Sunday. All those tweets were using the hashtag \#anakjaksel to make it easier in finding the Jaksel style.

\section{A. The words which are being used as Indoglish expressions}

The researchers identified the tweets and sorted the words which are being used as Indoglish expression in Jakarta Selatan. The words which are being used as Indoglish expression among them are listed below: Probably, confuse, skeptical, which is, enter, sandman, behind, don't look back in anger, so, problem, whatsoever, worth it, a little bit, IMO (in my opinion), stereotype, honestly, like, it, came out, automatically, I've been living, hangout, prefer, in, here, so far, Indonesian food, literally, fine-fine, please, my, statement, no, to, actually, bilingual, something, from, what, moreafter, hence its fine, me time, guys, confuse, well, no hard feeling, I don't care, shut up, next, two weeks, banana, Sunday.

The researchers listed the words which are mostly used from the result. They can be seen as follows:

Table 1. The most common words used as Indoglish expressions in Jaksel

\begin{tabular}{lc}
\hline \multicolumn{1}{c}{ Words } & Amount of Words \\
\hline So & 4 \\
Which/ which is & 4 \\
Literally & 5 \\
Prefer & 2 \\
\hline
\end{tabular}

\section{B. The analysis of Indoglish Phenomenon}

The researchers used four social dimensions in sociolinguistics to analyze the phenomenon from Holmes (2013). Four social dimensions in sociolinguistics to analyze the phenomenon from Holmes (2013).

\section{A social distance scale}

One of the factors which influence the linguistic choice is how well we know someone (Holmes, 2013). Holmes explains that the closer a person to a person the higher solidarity of language they get. Ariffin (2011) also said that the way people communicate reflects the uniqueness of language use (Aziz, 2003 as cited in Ariffin, 2011). Through this scale, the Indoglish phenomenon can be analyzed in the thick of intimacy relations among the speakers. This phenomenon happened among teenagers because the hashtag is \#AnakJaksel. The word "Anak" comes from Bahasa Indonesia which means children or teens while the word "Jaksel" stands for Jakarta Selatan. Therefore, owing to the meaning of the hashtag and the profile picture of the tweets, the speakers are teenagers. As the use of English among teenagers is easily found (Ariffin, 2011), those tweets come from various accounts which mostly are teenagers.

They choose to mix the language to communicate with others. "In social media, multilingual speakers often switch between languages" (Barman, 2014). As they know that their followers 
and friends are teenagers, they keep using Bahasa Indonesia and English as their "cool languages". Since code-mixing is a popular trend among social media users (Cardenas-Claros and Isharyanti, 2009; Shafie and Nayan, 2013 as cited in Barman, 2014), it's becoming a "trend" among them.

\section{A status scale}

This scale refers to the relevance of relative status (Holmes, 2013). As Watzlawick (2011) stated that all communication affects behaviour, people with higher status will get more respect terms. As an example, a student tends to call his/her headmaster with "Sir" rather than directly call his name. The researchers found two public figures who used code-mixing in their tweets. They're Ernest Prakasa and Sandiaga Uno. It's adequately shown that even public figure use this style to communicate.

In this paper, this example's slightly seen in Sandiaga's tweet. Sandiaga Uno was considered an older person in following this trend/phenomenon. He wrote his tweet by showing his picture with Ridwan Kamil (the Governor of West Java). The respect terms can be shown by the replies from some teenagers toward Sandiaga's tweet. Some of them gave their responses by commenting and calling him "Pak" or "Sir" in English. "A person can be polite, if the principles of politeness are applied in the community" (Darwis, 2018). The other tweets were created by mostly teenagers.

\section{A formality scale}

This scale is related to the setting or type of interaction of the phenomenon. It refers to the influence of social settings on language choice (Holmes, 2013). This phenomenon firstly appeared and took place in Jakarta Selatan (Jaksel).

The interaction happened through social media called "Twitter". Jaksel's teenagers tend to choose Bahasa Indonesia and English which are mixed into their daily conversation. Since there are so many International and National Plus Schools in Jakarta Selatan, the use of Bahasa Indonesia and English there is influenced by the formality setting (Holmes,2013). It's also supported by Linell (2004) that the acquisition of written language belongs to the so-called secondary socialization which means school or institution plays an important role. Since their environments denote bilingual societies, they're triggered to English as daily conversation. On the other hand, not all teenagers are competent English speakers. According to Kustati (2014), speakers of code-mixing /switching are not competent English speakers, and EFL students tend to use code-mixing since they do not know the appropriate translation of some words. Linguistic motivations were triggering the code-mixing in those highly bilingual societies ( $\mathrm{Li}, 2000$ and Macao, 2009 as cited in Barman, 2014) so Jaksel teenagers tend to mix the languages; Bahasa Indonesia and English in their daily conversation.

\section{Functional scales}

Functional scale refers to the purpose or topic of interaction. Holmes (2013) stated that language can convey objective information or express feelings. It can be seen that in this phenomenon, the speakers which mostly are teenagers were using Indoglish expression in their daily conversation because they wanted to be accepted. "Strong emotional arousal increases the frequency of code-mixing" (Dewaele as cited in Barman, 2014). The researchers saw this phenomenon as a trend since a hashtag (\#AnakJaksel) has been created since it's proven that code-mixing is a popular trend in social media users (Cardenas-Claros and Isharyanti, 2009; Shafie and Nayan, 2013 as cited in Barman, 2014). It is automatically shown the identity of Jaksel teenagers' language characteristics. As Kustanti (2014) stated that several signals like 
identity, equality, and mutual respect were taken place during cross-cultural communication. Indoglish expressions are used as prestige among Jaksel teenagers. It is supported by Inderasari (2019) that the use of Indoglish expression is seen as prestigious.

On the other hand, they used those expressions as jokes to become cool teenagers. As mentioned by Mabule that one of the 6 functions and reasons why people code mix or code switch; to affirm one's identity and sometimes social status (2015). Language is a human's ability to run good communication (Darwis, 2018) and the use of humour is highly valued in the interaction between people (Ritcie, 2004). In this phenomenon, Jaksel teenagers as the speakers used Indoglish expression or mixing the language to build good communication through jokes and humour. People code mix the language to make communication possible between different cultures and language groups (Mabule, 2015). It can be seen by the structure and meaning of the sentences. "The totality of linguistic resources available to the members of a community for socially significant interaction constitutes the linguistic repertoire of that community" (Calteaux, 1994).

\section{CONCLUSION}

This study aimed to identify the words which are mostly being produced and used as Indoglish expression and analyze the phenomenon. In conclusion, 78 English words were identified from 12 tweets in 8 websites as Indoglish expressions. There are as follows: probably, confuse, skeptical, which is, enter, sandman, behind, don't look back in anger, so, problem, whatsoever, worth it, a little bit, IMO (in my opinion), stereotype, honestly, like, it, came out, automatically, I've been living, hangout, prefer, in, here, so far, Indonesian food, literally, fine-fine, please, my, statement, no, to, actually, bilingual, something, from, what, moreafter, hence it's fine, me time, guys, confuse, well, no hard feeling, I don't care, shut up, next, two weeks, banana, and Sunday. On top of those tweets, there are 4 words which are mostly used such as so, which/which is, literally, prefer.

Meanwhile, the results of the analysis showed that this phenomenon happened among teenagers. In distinction to the social distance and status scale, it can be concluded that the relationship between the speakers are online friends and it is shown by the way they share their tweets using Indoglish expression through their social media called "Twitter". Based on the formality scale, this phenomenon also happened because of the setting and type of interaction. It happened in Jakarta Selatan, DKI Jakarta where we can find national plus and international schools. Thus, the environments denote bilingual societies and the teenagers tend to mix Bahasa Indonesia and English to communicate. Lastly, based on the functional scale, this phenomenon happened because the speakers wanted to be accepted. They used Indoglish expressions also as jokes since they think that using them as jokes will improve good interaction and communication among them. Eventually, they used Indoglish expressions as a prestige.

\section{ACKNOWLEDGMENTS}

We would like to express our gratitude to the editors of PROJECT (Professional Journal of English Education) for their editorship and Sanata Dharma University for the institutional support. 


\section{REFERENCES}

Ariffin, K., \& Susanti, H. M. (2011). Code-switching and code-mixing of English and Bahasa Malaysia in content-based classrooms: Frequency and attitudes. Linguistics Journal, 5(1).

Aziz, E. A. (2003). Indonesian English: what's del tuh?. TEFLIN Journal, 14(1), 140-148.

Barman, U., Das, A., Wagner, J., \& Foster, J. (2014, October). Code mixing: A challenge for language identification in the language of social media. Proceedings of the First Workshop on Computational Approaches to Code-switching (pp. 13-23).

Bell, A., \& Holmes, J. (Eds.). (1990). New Zealand ways of speaking English (Vol. 65). Multilingual Matters.

Calteaux, K. V. (1994). A sociolinguistic analysis of a multilingual community (Doctoral dissertation, University of Johannesburg).

Darwis, M. (2018). Politeness Language Analysis in Teenagers Reviewed from Sociolinguistics. Budapest International Research and Critics in Linguistics and Education (BirLE) Journal, 1(1), 15-22.

Garrett, P. B., \& Baquedano-López, P. (2002). Language socialization: Reproduction and continuity, transformation and change. Annual review of anthropology,31(1), $339-361$.

Holmes, J. (2013). An introduction to sociolinguistics. Routledge.

Holmes, J., Bell, A., \& Boyce, M. T. (1991). Variation and change in New Zealand English: A social dialect investigation. Wellington, New Zealand: Department of Linguistics, Victoria University.

Inderasari, E., \& Oktavia, W. (2019). Indoglish phenomenon: The power of media and business languages in the digitalization era. Jurnal Kata: Penelitian tentang Ilmu Bahasa dan Sastra, 3(2), 194-206.

Jaber, R. S. (2013). Gender and age effects on lexical choice in the Baghdadi speech community: A cognitive sociolinguistic analysis (Doctoral dissertation, Universiti Utara Malaysia).

Khotimah, K., Pribadi, F., \& Ahmadi, A. (2020, December). Indoglish in social media platforms and its significance as a national language planning material. International Joint Conference on Arts and Humanities (IJCAH 2020) (pp. 998-1007). Atlantis Press.

Kustati, M. (2014). An analysis of code-mixing and code-switching in EFL teaching of cross cultural communication context. Al-Ta lim Journal, 21(3), 174-182.

Linell, P. (2004). The written language bias in linguistics: Its nature, origins and transformations. Routledge.

Mabule, D. R. (2015). What is this? Is it code-switching, code-mixing or language alternating?. Journal of Educational and Social Research, 5(1), 339.

McMahon, A. M., \& April, M. (1994). Understanding language change. Cambridge University Press

Northrup, D. (2013). How English became the global language. Springer.

Rakhmawati, A., Saddhono, K., Hastuti, S., \& Devilito, R. (2016). A phenomenon of Indoglish usage at universities in Indonesia: Breaking down the motives from sociolinguistics perspective. Prosiding Prasasti, 146-152.

Rapley, T. (2018). Doing conversation, discourse and document analysis (Vol. 7). Sage.

Riadil, I. G., \& Nur, M. R. O. (2019). The Phenomenon of Indonglish Usage at Tidar University: Breaching The Motives from Sociolinguistics Perspectives.

Ritchie, G. (2004). The linguistic analysis of jokes (Vol. 2). Routledge. 
Roschelle, J. (2000). Choosing and using video equipment for data collection. Handbook of research design in mathematics and science education, 709-729.

Saddhono, K., \& Sulaksono, D. (2018, March). Indoglish as adaptation of English to Indonesian: change of society in big cities of Indonesia. In IOP Conference Series: Earth and Environmental Science 126 (2018) (Vol. 12092).

Saddhono, K., Rakhmawati, A., \& Hastuti, S. (2016). Indoglish phenomenon: The adaptation of English into Indonesian culture. Ponte, 72(3), 29-35.

Watzlawick, P., Bavelas, J. B., \& Jackson, D. D. (2011). Pragmatics of human communication: A study of interactional patterns, pathologies and paradoxes. WW Norton \& Company.

Wei, L., Milroy, L., \& Ching, P. S. (1992). A two- step sociolinguistic analysis of code- switching and language choice: the example of a bilingual Chinese community in Britain. International Journal of Applied Linguistics, 2(1), 63-86. 